\title{
PERAN PEMERINTAH DAN PARTISIPASI MASYARAKAT DALAM MUSYAWARAH PERENCANAAN PEMBANGUNAN DESA CARAWALI KECAMATAN WATTANG PULU KABUPATEN SIDENRENG RAPPANG
}

\author{
Kiki syani \\ Prodi administrasi publik Fakultas ilmu politik dan ilmu sosial \\ Universitas muhammadiyah rappang \\ kikisyani6@gmail.com
}

\begin{abstract}
Abstrak
Penelitian ini bertujuan untuk mengetahui Peran Pemerintah dan Partisipasi Masyarakat dalam Perencanaan Pembangunan di wilayah Kecamatan Gunungsari, terutama pada pelaksanaan Musrenbang Desa, di Desa Carawali Kecamata Wattang Pulu, Kabupaten Sidenreng Rappang.. Metode penelitian ini adalah penelitian deskriptif dengan pendekatan kualitatif, menggunakan analisa data kualitatif model interaktif. Hasil penelitian ini membuktikan bahwa belum maksimalnya partisipasi masyarakat dalam perencanaan Pembangunan dan peran Pemerintah masih terkesan bersifat elitis, dalam arti pemerintahlah yang menjadi penentu kebijakan pembangunan, sedangkan masyarakat berperan memberikan masukan kepada pemerintah tentang apa yang dibutuhkan oleh masyarakat.
\end{abstract}

Kata Kunci : Pemerintah, Partisipasi Masyarakat, Musrenbang

\section{PENDAHULUAN}

Negara didirikan dengan satu tujuan utama, yakni untuk memberikan kesejahteraan bagi masyarakat. Termasuk dalam hal ini antara lain adalah kemakmuran, kesehatan, pendidikan, dan rasa aman bagi rakyatnya serta meningkatkan harkat dan maratabat rakyat sebagai manusia. Oleh karena itu negara membentuk suatu organisasi yang bernama pemerintah sebagai pemegang mandat kekuasaan negara untuk merencanakan, menetapkan tujuan, dan sasaran. Untuk tercapainya keberhasilan pembangunan masyarakat di Daerah maka segala program perencanaan, pelaksanaan serta 
evaluasi pembangunan harus melibatkan masyarakat, karena merekalah yang mengetahui permasalahan dan kebutuhan dalam rangka membangun wilayahnya.(Wartika \& Fitriyah, 2017)

Sebagai bentuk pelaksanaan otonomi Daerah, peran Bupati/Walikota untuk menangani sebagian urusan dan kebijakan pemerintah daerah, dalam upaya pemenuhan pelayanan kepada masyarakat Bupati/Walikota meberikan tugas dan wewenang terhadap pemerintah Kecamatan, Camat memiliki kewenangan untuk membina penyelenggaran pemerintahan desa dalam bentuk memfasilitasi pembuatan peraturan desa dan terwujudnya adminstrasi tata pemerintahan yang baik.(Wartika \& Fitriyah, 2017)

Partisipasi memiliki maksud dasar menjadi instrumen yang memberikan peluang yang besar bagi masyarakat untuk dapat berkembang sesuai dengan potensinya, terlibat aktif dalam penyelenggaraan pemerintahan, sehingga pihaknya dapat menikmati mamfaat dari kebijakan, yang dibuat pihak pemerintah. Namun jika kita melihat ke belakang, bahwa mulai dari tahap perencanaan pembangunan yang menggunakan pola berjenjang dari bawah ke atas (Bottom-Up) ternyata tidak banyak menjanjikan aspirasi murni warga desa untuk didengar.(Latif et al., 2019)

Partisipasi diberi makna sebagai keterlibatan masyarakat dalam proses politik yang seluas-luasnya baik dalam proses pengambilan keputusan dan monitoring kebijakan yang dapat mempengaruhi kehidupan mereka. Berbagai peraturan yang memberikan ruang bagi partisipasi masyarakat secara substantif belum mengatur bagaimana partisipasi masyarakat itu dilaksanakan. Perlibatan masyarakat dalam proses pembuatan kebijakan pembangunan diatur secara bertahap sesuai dengan surat edaran Bersama Menteri Dalam Negeri dan Menteri Negara Perencanaan Pembangunan Nasional /Ketua Bappenas. Kondisi ini menunjukkan bahwa proses penyusunan kebijakan pembangunan bersifat elitis, dalam arti pemerintahlah yang menjadi penentu kebijakan pembangunan, sedangkan masyarakat berperan memberikan masukan kepada pemerintah tentang apa yang dibutuhkan oleh masyarakat. Apabila model ini diadopsi dalam upaya implementasi partisipasi masyarakat dalam pengambilan keputusan, maka yang dibutuhkan adalah keterbukaan pemerintah untuk menjadikan masukan masyarakat sebagai dasar dalam menyusun kebijakan publik.(Sapri, S., Mustanir, A., Ibrahim, M., Adnan, A. A., Wirfandi, 2019)

Partisipasi dapat berjalan lancar bila masyarakat memberikan 
kontribusi dalam proses kegiatan. Melalui berbagai macam bentuk partisipasi inilah masyarakat bisa ikut terlibat dan dapat bertanggung jawab atas program yang di berikan oleh pemerintah, sehingga masyarakat dapat memanfaatkan dan menggunakan dengan baik. Partisipasi masyarakat dalam pelaksanaan program pembangunan masih kurang baik yang ditunjukan dengan adanya masalah-masalah klasik yang sering terjadi di dalam masyarakat dengan tidak aktifnya anggota masyarakat mengikuti setiap acara rapat dan kegiatan musyawarah.(Nurhastuti, 2019)

Pelibatan masyarakat dalam proses pembuatan kebijakan pembangunan diatur secara bertahap sesuai dengan Surat Edaran Bersama Menteri Dalam Negeri dan Menteri Negara Perencanaan Pembangunan Nasional/Ketua Bappenas. Kondisi ini menunjukkan bahwa proses penyusunan kebijakan pembangunan bersifat elitis, dalam arti pemerintahlah yang menjadi penentu kebijakan pembangunan, sedangkan masyarakat berperan memberikan masukan kepada pemerintah tentang apa yang dibutuhkan oleh masyarakat.(Wartika \& Fitriyah, 2017)

\section{KAJIAN PUSTAKA}

\section{A. Aparatur Pemerintah Desa}

Pemerintahan Desa adalah penyelenggaraan urusan pemerintahan oleh pemerintah desa dan Badan Permusyawaratan Desa dalam mengatur dan mengurus kepentingan masyarakat setempat berdasarkan asal-usul dan adat istiadat setempat yang diakui dan dihormati dalam sistem Pemerintahan Negara Kesatuan Republik Indonesia (A. Mustanir and Yasin 2018) (Mustanir, Ahmad; Barisan, Barisan; Hamid 2017).(Mustanir et al., 2018)

\section{B. Konsep Partisipasi Masyarakat}

Partisipasi anggota masyarakat merupakan keterlibatan anggota masyarakat dalam pembangunan, meliputi kegiatan dalam perencanaan dan pelaksanaan (implementasi) program/proyek pembangunan yang dikerjakan di dalam masyarakat. Sedangkan Partisipasi masyarakat dalam pembangunan diartikan ikut sertanya masyarakat dalam pembangunan, ikut dalam kegiatan pembangunan dan ikut serta pemanfaatan dan menikmati hasil pembangunan.(Mustanir \& Abadi, 2017) 
Partispasi masyarakat merupakan suatu proses yangdapat mendukung masyarakat untuk mulai "sadar" akan situasi dan masalah yang dihadapinya serta berupaya mencari jalan keluar yangdapat dipakai untuk mengatasi masalah mereka (memiliki kesadaran kritis). Sumardi (2010:46), mengemukakan bahwa partisipasi adlah peran serta seseorang atau kelompok masyarakat dalam proses pembangunan baik dalam bentuk pernyataan maupun dalam bentuk kegiatan dengan memberi masukan pikiran, tenaga, waktu, keahlian, modal, dan atau materi, serta ikut memanfaatkan dan menikmati hasil-hasil pembangunan.(Sulaeman et al., 2019)

Menurut Adisasmita (2006) menyatakan, "Partisipasi masyarakat adalah pemberdayaan masyarakat, peran sertanya dalam kegiatan penyusunan perencanaan dan implementasi program/proyek pembangunan, dan merupakan aktualisasi dan kesediaan dan kemauan masyarakat untuk berkorban dan berkontribusi terdahap implementasi program pembangunan"(Ibrahim et al., 2020)

Menurut Nurman (2015:252) (Mustanir, Sellang, et al. 2018) (Mustanir and Rusdi. Muhammad 2019) Partisipasi masyarakat adalah keikutsertaan masyarakat dalam pengambilan keputusan, pemanfaatan sumber daya, pemecahan masalah yang berkaitan dengan pembangunan desa.(Sapri, S., Mustanir, A., Ibrahim, M., Adnan, A. A., Wirfandi, 2019)

Masyarakat dipandang sebagai elemen yang terpenting dalam proses pembangunan, apalagi perlu disadari percepatan pembangunan harus dimulai dari bottom-up, yaitu mengerakkan masyarakat agar berperan aktif dalam memajukan pembangunan. Titik sentral pembangunan memang terlihat dari partisipasi aktif masyarakatnya. Berkeinginan merubah dan memiliki keinginan untuk dirubah, merupakan aset terpenting untuk memberdayakan masyarakat.(Latif et al., 2019)

Konsep partisipasi, dalam perkembangannya, memiliki pengertian yang beragam walaupun dalam beberapa hal memiliki persamaan. Dalam konsep pembangunan, pendekatan partisipasi paling tidak memiliki tiga makna. Pertama, partisipasi dimaknai sebagai kontribusi masyarakat untuk meningkatkan efisiensi dan efektifitas pembangunan dalam mempromosikan proses demokratisasi dan pemberdayaan. Kedua, pendekatan ini dikenal sebagai partisipasi dalam dikotomi instrumen dan tujuan. Konsep ketiga, partisipasi dimaknai sebagai sebuah situasi dimana pejabat lokal, tokoh masyarakat, LSM, birokrasi dan aktor-aktor lain yang 
terlibat langsung dengan program partisipatif, melakukan praktik yang jauh dari prinsip partisipasi.(Mustanir \& Abadi, 2017)

Beberapa alasan mengapa masyarakat perlu diajak untuk berperan serta dan didorong untuk berpartisipasi, sebagaimana yang ditulis Adisasmita (2006), yaitu:

a. Masyarakat memahami sesungguhnya tentang keadaan lingkungan sosial dan ekonomi masyarakatnya;

b. Masyarakat mampu menganalisis sebab dan akibat dari berbagai kejadian yang terjadi dalam masyarakat;

c. Masyarakat mampu merumuskan solusi untuk mengatasi permasalahan dan kendala yang dihadapi masyarakat;

d. Masyarakat mampu memanfaatkan sumber daya pembangunan (SDA, SDM, dana, teknologi) yang dimiliki untuk meningkatkan produksi dan produktivitas dalam rangka mencapai sasaran pembangunan masyarakatnya; dan

e. Masyarakat dengan upaya meningkatkan kemampuan SDM- nya dan kemauan, sehingga dengan berlandaskan pada kepercayaan diri dan keswadayan yang kuat mampu menghilangkan sebagian besar ketergantungan terhadap pihak luar.(Latif et al., 2019)

Solekhan (2014:153) mengatakan bahwa bentuk partisipasi masyarakat pada intinya ada (empat) macam, yaitu :

a. Partisipasi dalam pembuatan keputusan

b. Partisiasi dalam pelaksanaan

c. Partisipasi dalam menerima manfaat

d. Partisipasi dalam evaluasi(Kepemimpinan et al., 2019)

\section{Musyawarah Perencanaan Pembangunan}

Musrenbang adalah forum-forum multi-pihak terbuka yang secara bersama mengidentifikasi dan menentukan prioritas kebijakan pembangunan masyarakat. Musrenbang kelurahan adalah forum musyawarah tahunan para pemangku kepentingan (stakeholders) kelurahan untuk menyepakati rencana kerja kelurahan tahun anggaran berikutnya.(Sapri, S., Mustanir, A., Ibrahim, M., Adnan, A. A., Wirfandi, 2019)

Musrenbang adalah forum-forum multi-pihak terbuka yang secara bersama mengidentifikasi dan menentukan prioritas kebijakan 
pembangunan masyarakat. Musyawarah perencanaan pembangunan (musrenbang) kelurahan adalah forum musyawarah tahunan para pemangku kepentingan (stakeholders) kelurahan untuk menyepakati rencana kerja kelurahan tahun anggaran berikutnya. Tim Kerja Buku Panduan Penyelenggaraan Musrenbang dalam Ahmad Mustanir (2016).(Mustanir \& Rusdi, 2019)

Musrenbang adalah sebuah mekanisme perencanaan, sebuah institusi perencana yang ada di daerah dan sebagai mekanisme untuk mempertemukan usulan/kebutuhan masyarakat (bottom up planning) dengan apa yang akan diprogram pemerintah (tp down planning)(A. Mustanir 2018b) (A. Mustanir 2017).(Mustanir et al., 2018)

Musrenbang adalah Perencanaan Pembangunan Bersama Masyarakat adalah merupakan panduan atau model pembangunan kelurahan yang menitikberatkan pada peran serta masyarakat dalam keseluruhan proses pembangunan 16 . Pendekatan ini dilandasi oleh nilai-nilai dan semangat gotong-royong yang telah mengakar dalam budaya masyarakat Indonesia. Gotong-royong bertumpu pada keyakinan bahwa setiap warga masyarakat memiliki hak untuk memutuskan dan merencanakan apa yang terbaik bagi diri dan lingkungan serta cara terbaik dalam upaya mewujudkannya.(Mustanir \& Abadi, 2017)

Pengertian pembangunan diartikan sebagai suatu "proses" pembangunan sebagai proses menggambarkan adanya pengembangan baik meliputi proses pertumbuhan ataupun perubahan dalam kehidupan bersama (organisasi) sosial dan budaya (Mustanir \& Darmiah, 2016). Hal ini merupakan gambaran umum masyarakat luas (society)(Latif et al., 2019)

Perencanaan pembangunan merupakan suatu tahapan awal dalam proses pembangunan. Sebagai tahapan awal, perencanaan pembangunan akan menjadi bahan/pedoman/acuan dasar bagi pelaksanaan kegiatan pembangunan (Riyadi \& Bratakusumah, 2004) (Mustanir and Rusdi. Muhammad(Mustanir et al., 2020)

Perencanaan pembangunan juga berlaku bagi negara-negara yang sedang berkembang, karena ada bebrapa faktor, yaitu karena kegagalan mekanisme pasar, ketidakpastian masa datang, untuk mengarahkan kegiatan pembangunan. Indonesia merupakan salah satu negara berkembang yang tak luput dengan mekanisme parencanaan pembangunan dengan adanya SPPN (system perencanaan pembangunan nasional) Undang-Undang Nomor 24 Tahun 2004. Yang mana perencanaan pembangunan bukan 
hanya dilakukan pada tingkat pusat namun pada tingkat daerah juga.(Mustanir et al., 2020)

Dalam konteks pelaksanaan pembangunan daerah, sesuai dengan peran pemerintah daerah dalam era otonomi luas, perencanaan pembangunan daerah diperlukan kerana pelaksanaan pembangunan didesentralisasikan dari pemerintah pusat kepada pemerintah daerah.(Mustanir et al., 2020)

Ahmad 2015: 32; Nared, Razpotnik Viskoovic, Cremer-Schulte, Brozzi, \& Cortines Garcia, 2015; Mckenna-Cress \& Kamien, n.d ; Kariuki \& Njuki, 2013; Hossen, 2016; Bhattacharyya, 2004) mengungkapkan bahwa garisgaris besar perencanaan desa mengandung pengertian sebagai berikut :

a. Perencanaan adalah rangkaian kegiatan analisis mulai dari identifikasi kebutuhan sampai dengan penetapan program-program pembangunan

b. Perencanaan pembangunan berdasar pada masalah, kebutuhan dan potensi masyarakat.

c. Perencanaan pembangunan di desa menjadi wujud nyata peran serta masyarakat dlam membangun masa depannya.

d. Perencanaan pembangunan diharapkan dapat memberikan dampak pada peningkatan kesejahteraan dan perdamaian(Kepemimpinan et al., 2019)

\section{METODE PENELITIAN}

Jenis penelitian yang digunakan dalam penelitian ini menggunakan penelitian deskriptif dengan pendekatan kualitatif. Sumber data berasal dari informan, dan dokumen. Lokasi penelitian di Desa Carawali Kecamata Wattang Sidenreng, Kabupaten Sidenreng Rappang. Teknik pengumpulan data melalui wawancara, observasi dan dokumentasi. Metode analisia data menggunakan analisa data kualitatif model interaktif (Miles, Huberman dan Saldana, 2014), yaitu pengumpulan data, kondensasi data, penyajian data, serta penarikan kesimpulan(Wartika \& Fitriyah, 2017) 


\section{PEMBAHASAN}

Musrenbang dilaksanakan di setiap tingkatan, mulai tingkat kelurahan/Desa,kecamatan, kabupaten/kota hingga tingkat nasional. Musrenbang Desa di Kecamatan Gunungsari adalah forum musyawarah tahunan yang dilakukan di tingkat bawah untuk mendapatkan usulan-usulan dan merumuskan usulan tersebut untuk direncanakan pada tahap Musrenbang selanjutnya, yang nantinya menjadi masukan dalam penyusunan rencana kerja pemerintah daerah (RKPD) Kabupaten Sidenreng Rappang. Penyusunan perencanaan pembangunan harus berdasarkan data dan informasi yang akurat dan dapat dipertanggungjawabkan. Artinya, rencana pembangunan desa itu harus disusun berdasarkan kenyataan yang ada di suatu daerah, baik itu berupa masalah maupun potensi yang dimiliki suatu daerah. Dengan demikian, perencanaan pembangunan daerah yang tersusun dapat sesuai dengan kebutuhan pembangunan, bukan sekedar daftar keinginan yang jauh dari kenyataan dan kemampuan untuk mewujudkannya.(Wartika \& Fitriyah, 2017)

Musyawarah Perencanaan Pembangunan (Musrenbang) menjadi media pemerintah untuk melibatkan partisipasi masyarakat. Pelibatan masyarakat dalam pembangunan sudah tentu mutlak adanya, disamping merangkul keikutsertaan masyarakat itu sendiri, partisipasi yang diberikan secara tidak langsung memberi peningkatan kapasitas program yang dijalankan, maupun bagi masyarakat itu sendiri.(Latif et al., 2019)

Fokus utama dari Musrenbang adalah adalah forum perencanaan (program) yang dilaksanakan oleh lembaga publik yaitu pemerintah desa, bekerja sama dengan warga dan para pemangku kepentingan lainnya. Musrenbang yang bermakna akan mampu membangun kesepahaman tentang kepentingan dan kemajuan desa, dengan cara memotret potensi dan sumber-sumber pembangunan yang tidak tersedia baik dari dalam maupun luar desa.(Latif et al., 2019)

Partisipasi masyarakat dalam mengikuti rapat Musrenbang di Desa Carawali dikategorikan sangat baik dengan nilai rata-rata persentase 83,6\%. Musyawarah Perencanaan Pembangunan (Musrenbang) menjadi media pemerintah untuk melibatkan partisipasi masyarakat. Pelibatan masyarakat dalam pembangunan sudah tentu mutlak adanya, disamping merangkul keikutsertaan masyarakat itu sendiri, partisipasi yang diberikan secara tidak langsung memberi peningkatan kapasitas program yang dijalankan, maupun bagi masyarakat itu sendiri.(Latif et al., 2019)

partisipasi masyarakat adalah suatu aktivitas yang mengikutsertakan perasaan dan emosional seseorang dalam proses pembuatan keputusan dan melaksanakan tanggung jawab dalam suatu organisasi atau kelompok dalam mencapai tujuan bersama yang telah ditetapkan.(Mustanir \& Abadi, 2017) 
Sehingga disimpulkan partisipasi masyarakat merupakan "proses ketika warga,sebagai individu maupun kelompok sosial dan warga, mengambil peran serta, ikut mempengaruhi proses perencanaan, pelaksanaan dan pemantauan kebijakan-kebijakan yang langsung mempengaruhi kehidupan mereka".(Mustanir \& Abadi, 2017)

\section{KESIMPULAN}

1. Bahwa proses pelaksanaan musrenbang di wilayah kecamatan Wattang Pulu belum sepenuhnya mengacu pada peraturan dan Undang-Undang, hal ini terbukti dari belum melaksanakan beberapa tahapan perencanaan pada pelaksanaan Musrenbang Desa

2. Partisipasi masyarakat pada pelaksanaan Musrenmbang Desa di Kecamatan Wattang Pulu masih pada tahapan melaksanakan, memberikan saran dan menikmati hasil perencanaan tersebut, belum sepenuhnya terlibat pada semua tahapan Perencanaan, seperti merencanakan, menetukan dan memutuskan

3. Peran Pemerintah Kecamatan maupun pemerintah Desa pada pelaksanaan Musrenbang di Kecamatan Wattang Pulu terkesan masih mendominasi pada setiap tahapan Musrenbang sehingga perencanaan tersebut masih bersifat elitis dalam artian pemerintahlah yang menjadi penentu kebijakan pembangunan, sedangkan masyarakat berperan memberikan masukan kepada pemerintah tentang apa yang dibutuhkan oleh masyarakat. 


\section{DAFTAR PUSTAKA}

Ibrahim, M., Mustanir, A., Adnan, A. A., \& Alizah P, N. (2020). Pengaruh Manajemen Pengelolan Badan Usaha Milik Desa terhadap Peningkatan Partisipasi Masyarakat di Desa Bila Riase Kecamatan Pitu Riase Kabupaten Sidenreng Rappang. Movere Journal, 2(2), 56-62. https://ojs.stie-tdn.ac.id/index.php/MV/article/view/118

Kepemimpinan, A., Optimalisasi, T., Pada, M., \& Pembangunan, P. (2019). Analisis Kepemimpinan Terhadap Optimalisasi Masyarakat Pada Perencanaan Pembangunan Di Enrekang. 1-20. https://doi.org/10.20956/xxxxxx

Latif, A., Rusdi, M., Mustanir, A., \& Sutrisno, M. (2019). Partisipasi Masyarakat Dalam Pembangunan Infrastruktur Di Desa Timoreng Panua Kecamatan Panca Rijang Kabupaten Sidenreng Rappang Dosen Ilmu Pemerintahan Stisip Muhammadiyah Rappang Dosen Ilmu Administrasi Negara Stisip Muhammadiyah Rappang 5). Jurnal MODERAT, $5(1)$, $1-15$. https://jurnal.unigal.ac.id/index.php/moderat/article/view/1898

Mustanir, A., \& Abadi, P. (2017). Partisipasi Masyarakat Dalam Musyawarah Rencana Pembangunan Di Kelurahan Kanyuara Kecamatan Watang Sidenreng Kabupaten Sidenreng Rappang. Jurnal Politik Profetik, 5(2), 247-261. http://journal.uinalauddin.ac.id/index.php/jpp/article/viewFile/4347/3986\%0Ahttp://jour nal.uin-alauddin.ac.id/index.php/jpp/issue/view/636

Mustanir, A., Fitriani, S., Adri, K., Nurnawati, A. A., \& Goso, G. (2020). Sinergitas Peran Pemerintah Desa dan Partisipasi Masyarakat Terhadap Perencanaan Pembangunan di Kabupaten Sidenreng Rappang (The Synergy of Village Government's Role and Community Participation in the Process of Development Planning in Sidenreng Rappang D. Journal of Government Science (GovSci), 2020(2), 84-108.

Mustanir, A., Kamarudding, S., Akhwan, A., Madaling, \& Mutmainna. (2018). Peranan Aparatur Pemerintahan Desa dan Partisipasi Masyarakat Dalam Musyawarah Perencanaan Pembangunan di Desa Tonrongnge Kecamatan Baranti Kabupaten Sidenreng Rappang. Jurnal Ilmiah Clean Government, 2(Desember), 67-84. http://lonsuit.unismuhluwuk.ac.id/index.php/clean/article/view/213

Mustanir, A., \& Rusdi, M. (2019). Participatory Rural Appraisal (PRA) Sebagai Sarana Dakwah Muhammadiyah Pada Perencanaan Pembangunan di Kabupaten Sidenreng Rappang. Prosiding Konferensi Nasional Ke-8 Asosiasi Program Pascasarjana Perguruan Tinggi Muhammadiyah Aisyiyah (APPPTMA), 467-475. 
http://asosiasipascaptm.or.id/index.php/publikasi/prosiding-konferensinasional-appptma-ke-8

Nurhastuti. (2019). No 主観的健康感を中心とした在宅高齢者における 健康関連指標に関する共分散構造分析Title. 2(2), 145-172.

Sapri, S., Mustanir, A., Ibrahim, M., Adnan, A. A., Wirfandi, W. (2019). Peranan Camat dan Partisipasi Masyarakat Dalam Musyawarah Perencanaan Pembangunan Di Kecamatan Enrekang Kabupaten Enrekang. MODERAT: Jurnal Ilmiah Ilmu Pemerintahan, 5(2), 33-48. https://jurnal.unigal.ac.id/index.php/moderat/article/view/2127

Sulaeman, Z., Mustanir, A., \& Muchtar, A. I. (2019). Partisipasi Masyarakat Terhadap Perwujudan Good Governance Di Desa Damai Kecamatan Watang Sidenreng Kabupaten Sidenreng Rappang. PRAJA: Jurnal Ilmiah Pemerintahan, 7(3), 88-92. https://doi.org/10.51817/prj.v7i3.374

Wartika, I., \& Fitriyah, Z. (2017). Peran Pemerintah Dan Partisipasi Masyarakat Dalam Perencanaan Pembangunan Daerah. Neo Bis, 1(1), 28-40. http://journal.trunojoyo.ac.id/neo-bis/article/view/2952 